\title{
EFEITO ALELOPÁTICO DOS EXTRATOS HEXÂNICO E METANÓLICO OBTIDOS DOS FRUTOS VERDES DE Solanum lycocarpum A. St. Hil. SOBRE Lactuca sativa (ALFACE)
}

\author{
Izabela C. A. Silva*, Juliana C. Fonseca, Luciana A. R. dos Santos Lima \\ Laboratório de Fitoquímica - Universidade Federal de São João Del Rei-UFSJ - Campus Centro-Oeste Dona Lindu- \\ Divinópolis/MG. \\ email: izacaputo@hotmail.com
}

\section{Resumo}

A espécie vegetal Solanum lycocarpum A. St. Hil., da família Solanaceae, popularmente conhecida como lobeira, cresce e se desenvolve em condições ambientais desfavoráveis, tais como terras ácidas e pobres em nutrientes. É capaz de suportar um clima árido e períodos de seca prolongados, resistindo ainda a ciclos anuais de queimadas feitas pelo homem. Por suas características vitais, o presente trabalho teve como objetivo verificar o efeito alelopático dos extratos hexânico e metanólico obtidos dos frutos verdes de Solanum lycocarpum sobre radículas e hipocótilos de Lactuca sativa (alface). Os frutos de Solanum lycocarpum foram coletados, triturados manualmente e submetidos à extração em aparelho de Soxhlet com hexano e, posteriormente, com metanol. O ensaio de atividade alelopática foi feito com sementes de Lactuca sativa $\mathrm{L}$. $\mathrm{O}$ crescimento das sementes foram conduzidos em solução tampão MES [ácido 2(N-morfolino)etanosulfônico] na concentração de $1,95 \mathrm{~g} / \mathrm{L}$ e os extratos hexânico e metanólico foram testados nas concentrações de 200, 100 e 50 $\mu \mathrm{g} / \mathrm{mL}$. Foram distribuídas 25 sementes de Lactuca sativa (alface) em placas de petri e adicionados $7 \mathrm{~mL}$ de solução tampão contendo as amostras ou $7 \mathrm{~mL}$ dos controles (solução tampão sem qualquer amostra testada). As placas foram incubadas por dez dias em Câmara de Germinação, a $25{ }^{\circ} \mathrm{C}$. Depois, o comprimento das radículas e dos hipocótilos foi medido. Os resultados obtidos no experimento mostraram maior inibição do hipocótilo com o extrato hexânico, na concentração de $200 \mu \mathrm{g} / \mathrm{mL}$, e com o metanólico, na concentração de 50 $\mu \mathrm{g} / \mathrm{mL}$. Em relação à radícula, o extrato hexânico na concentração de 100 $\mu \mathrm{g} / \mathrm{mL}$ e o metanólico na concentração de $50 \mu \mathrm{g} / \mathrm{mL}$ apresentaram maior 
porcentagem de inibição. Os extratos hexânico e metanólico de Solanum lycocarpum A. St. Hil. apresentaram efeito alelopático sobre radículas e hipocótilos de Lactuca sativa (alface).

Palavras-chave: Solanum lycocarpum, alface, efeito alelopático.

Apoio financeiro: CNPq, FAPEMIG, UFSJ. 